\title{
Soil Aggregation and Organic Carbon Fractions and Indices in Conventional and Conservation Agriculture under Vertisol soils of Sub-tropical Ecosystems: A Review
}

\author{
Arvind Kumar', R. K. Naresh', Shivangi Singh ${ }^{2 *}$, N. C. Mahajan ${ }^{3}$ and Omkar Singh ${ }^{2}$ \\ ${ }^{1}$ Barkatullah University, Bhopal, (M.P.), India \\ ${ }^{2}$ Department of Agronomy, Sardar Vallabhbhai Patel University of Agriculture and \\ Technology, Meerut, (UP), India \\ ${ }^{3}$ Department of Agronomy, Institute of Agricultural Sciences; \\ Banaras Hindu University, Varanasi-(U.P), India \\ *Corresponding author
}

\section{A B S T R A C T}

\begin{tabular}{|l|}
\hline Ke y w o r d s \\
Microbial biomass, \\
$\begin{array}{l}\text { Conservation } \\
\text { tillage, Organic } \\
\text { matter dynamics, } \\
\text { Biological activity }\end{array}$ \\
\hline Article Info \\
\hline $\begin{array}{l}\text { Accepted: } \\
\text { 17 September } 2019 \\
\text { Available Online: } \\
\text { 10 October } 2019\end{array}$ \\
\hline
\end{tabular}

\section{Keywords}

Microbial biomass, Conservation tillage, Organic matter dynamics, Biological activity

Accepted: 17 September 2019 Available Online:
Tillage systems can changes in soil organic carbon dynamics and soil microbial biomass by changing aggregate formation and $\mathrm{C}$ distribution within the aggregate. However, the effects of tillage method or straw return on soil organic C (SOC) have showed inconsistent results in different soil/climate/ cropping systems. Soil TOC and labile organic $\mathrm{C}$ fractions contents were significantly affected by straw returns, and were higher under straw return treatments than non-straw return at three depths. The soil organic carbon (SOC) stock in bulk soil was 40.2-51.1\% higher in the 0.00-0.05 m layer and 11.3-17.0\% lower in the 0.05-0.20 m layer in NT system no-tillage without straw (NT-S) and with straw (NT+S), compared to the MP system moldboard plow without straw (MP-S) and with straw $(\mathrm{MP}+\mathrm{S})$, respectively. Residue incorporation caused a significant increment of $15.65 \%$ in total water stable aggregates in surface soil (0$15 \mathrm{~cm})$ and $7.53 \%$ in sub-surface soil $(15-30 \mathrm{~cm})$. In surface soil, the maximum $(19.2 \%)$ and minimum (8.9\%) proportion of total aggregated carbon was retained with $>2 \mathrm{~mm}$ and $0.1-0.05 \mathrm{~mm}$ size fractions, respectively. At $0-7 \mathrm{~cm}$ depth, soil $\mathrm{MBC}$ was significantly higher under plowing tillage than rotary tillage, but EOC was just opposite. Rotary tillage had significantly higher soil TOC than plowing tillage at 7-14 $\mathrm{cm}$ depth. However, at $14-21 \mathrm{~cm}$ depth, TOC, DOC and MBC were significantly higher under plowing tillage than rotary tillage except for EOC. A considerable proportion of the total SOC was found to be captured by the macro-aggregates $(>2-0.25 \mathrm{~mm})$ under both surface $(67.1 \%)$ and sub-surface layers $(66.7 \%)$ leaving rest amount in micro-aggregates and 'silt + clay' sized particles. Application of inorganic fertilizer could sustain soil organic carbon (SOC) concentrations, whereas long-term application of manure alone or combined with NPK (M and NPK + M) significantly increased SOC contents compared with the unfertilized control. Manure application significantly increased the proportion of large macro-aggregates (> $2000 \mu \mathrm{m}$ ) compared with the control, while leading to a corresponding decline in the percentage of micro-aggregates $(53-250 \mu \mathrm{m})$. Carbon storage in the intra-aggregate particulate organic matter within micro-aggregates was enhanced from $9.8 \%$ of the total SOC stock in the control to $19.7 \%$ and $18.6 \%$ in the $\mathrm{M}$ and NPK + M treatments, respectively. The shift in SOC stocks towards micro-aggregates is beneficial for long-term soil $\mathrm{C}$ sequestration. Moreover, the differences in the micro-aggregate protected $\mathrm{C}$ accounted, on average, for $39.8 \%$ of the differences in total SOC stocks between the control and the manure-applied treatments. Thus, we suggest that the micro-aggregate protected $\mathrm{C}$ is promising for assessing the impact of conventional and conservation agriculture on SOC storage in the vertisol. Soil disturbance by tillage leads to destruction of the protective soil aggregate. This in turn exposes the labile $\mathrm{C}$ occluded in these aggregates to microbial breakdown. The present study found that SOC change was significantly influenced by the crop residue retention rate and the edaphic variable of initial SOC content. 


\section{Introduction}

More than two-thirds of terrestrial carbon is stored in the soil. There is approximately 1500 $\mathrm{Pg} \mathrm{C}\left(1 \mathrm{Pg}=10^{9} \mathrm{Mg}=10^{15} \mathrm{~g}\right)$ stored as SOC in the top $1 \mathrm{~m}$ (Stockmann et al., 2013). The rest of the terrestrial carbon (560 Pg) is stored in plant biomass (Paustian et al., 1997). Oceans store the largest amount of carbon $(38,000 \mathrm{Pg})$ (Stockmann et al., 2013), whereas the atmosphere stores less carbon than there is in the soil (750 Pg) (Paustian et al., 1997). Anthropogenic carbon emissions (e.g. fossil fuel combustion, cement manufacturing), in the form of carbon dioxide $\left(\mathrm{CO}_{2}\right)$, have increased in the past 35 years. In the 1980s, anthropogenic carbon emissions was $6 \mathrm{Pg} \mathrm{yr}^{-1}$ (Lal and Follett, 2009), and by 2014, the anthropogenic carbon emissions had increased to $10 \mathrm{Pg} \mathrm{yr}^{-1}$ (Zeebe et al., 2016). Soils are considered a carbon sink, which can help decrease the atmospheric $\mathrm{CO}_{2}$ concentration and reduce the greenhouse effect (Jaffe, 1970). Storage of SOC is affected by climate, land cover, soil order, and soil texture (Batjes, 2016). It has been reported that soils under deserts store the lowest amount of SOC, and the soils under tropical forests store the highest amount of SOC (Batjes, 2016). Much of the carbon in deserts may be stored in inorganic form (Eswaran et al., 2000). About $8 \%$ of SOC is stored in soils under agriculture (Jobbagy and Jackson, 2000). Carbon storage is affected by soil texture and aggregation, and the silt and clay size fractions have the ability to protect SOC from decomposition (Hassink, 2016). When organic matter decomposes, the organic matter binds with silt and clay forming aggregates, which protects the organic matter from decomposition (Churchman, 2018). Hassink (2016) found no relationship between total carbon and and clay + silt content, but there was an increase in the soil carbon stored in $<20 \mu \mathrm{m}$ size fraction with an increase in clay+ silt content. Gabarron Galeote et al., (2015) and Tiessen and Stewart
(1983) found that the highest amount of soil carbon is found in the silt and clay size fractions, and the sand sized fraction is low in soil carbon.

Soil organic matter/carbon (SOM/SOC) has profound effects on soil physical, chemical and biological properties (Haynes, 2005). Maintenance of SOM/SOC in cropland is important, not only for improvement of agricultural productivity but also for reduction in C emission (Rajan et al., 2012). However, short- and medium-term changes of SOC are difficult to detect because of its high temporal and spatial variability (Blair et al., 1995). On the contrary, soil labile organic C (LOC) fractions i.e. microbial biomass $\mathrm{C}$ (MBC), dissolved organic $\mathrm{C}$ (DOC), and easily oxidizable $\mathrm{C}$ (EOC) that turn over quickly can respond to soil management intervention more rapidly than total organic carbon (TOC) [Haynes, 2005; Yadvinder-Singh et al., 2005). Therefore, LOC fractions have been considered as early sensitive indicators of the effects of land use change on soil quality and soil health [Rudrappa et al., 2006; Yang et al., 2005; Yadvinder-Singh et al., 2005). Agricultural practices such as tillage methods are conventionally used for loosening soils to grow crops.

At the same time, long-term soil disturbance by tillage is believed to be one of the major factors reducing SOC in agriculture (Baker $e t$ al., 2005). Nevertheless, SOC pool plays a significant role in the global carbon cycle and is a key determinant of the physical, chemical and biological properties and is required for the proper functioning of the soil system. Soil aggregation (macro- and micro-) and stability can have a large effect on SOC dynamics and sequestration, and $\mathrm{C}$ availability. Soil macroaggregates affect $\mathrm{C}$ storage by occluding organic residues, making them less accessible to degrading organisms and their enzymes (Six et al., 2000). 
Soil organic carbon (SOC) plays an important role in the formation and stabilization of soil aggregates (Spohn and Giani, 2011). There exists a close relationship between soil aggregation and SOC accumulation; generally SOC promotes soil aggregation, whereas aggregates, in turn, store SOC and reduce the rate of its decomposition. The stable soil aggregates act as the nuclei for long-term stabilization of SOC. These protect the SOC by forming physical barriers between microbes and enzymes and thus reduce SOC turnover rate (Pulleman and Marinissen, 2004). The size and stability of aggregates is determined by the quality and quantity of humic compounds and the degree of their interaction with the soil particles (Jastrow and Miller, 1998). The extent of carbon retention in soil depends on the nature of aggregation (Carter, 1996), degree of physico-chemical characteristics and stabilization of organic carbon inside the aggregates (Debasish et al., 2011). Dynamics of soil aggregation and SOC are strongly influenced by land use changes and their management practices (Kumar et al., 2013). Land use change may alter the soil physico-chemical properties, soil microbial composition and functioning of rhizosphere (Maharning et al., 2009). These changes may affect soil structural stability, soil aggregation and on some occasions, favours one microbial sub-group on the expense of other groups, thereby affecting the SOC storage and nutrient turnover in soils (Belay-Tedla et al., 2009).

Microorganisms through their enzymatic activities help in maintaining the soil ecosystem function by degrading soil organic matter, catalyzing the biochemical reactions involved in nutrient cycling and energy transfer (Sinsabaugh et al., 1991). Microbial activities are therefore, recognized as possible indicators of the changes in soil management and are believed to indicate early responses to changes in management practices (Bandick and Dick, 1999). The SOC is recognized to consist of various fractions varying in degree of decomposition, recalcitrance and turnover rate (Huang et al., 2008). These fractions can be classified as labile, semi-labile and recalcitrant (Stevenson, 1994). These fractions exhibit different rates of biochemical and microbial degradation (Stevenson, 1994). Generally, presence of different SOC fractions in soil reflect key processes of nutrient cycling and availability, soil aggregation and stability and soil carbon accrual (Wander, 2004). Due to spatial variability of soils, the SOC losses or gains in a short time are difficult to directly measure. Therefore, it is now becoming more evidential that the labile fractions of SOC such as cold water extractable organic carbon, hot water extractable organic carbon, microbial biomass carbon, carbohydrate carbon, particulate organic matter are mainly used to detect changes associated with land use. The SOC fractions have comparatively rapid turnover rate (Von-Lutzow et al., 2002), respond rapidly to changes in management practices and are more sensitive indicators of the effects of land use as compared to total soil organic carbon (He et al., 2008).

\section{Aggregate distribution and stability}

Aggregate stability refers to the ability of soil aggregates to resist disintegration when disruptive forces associated with tillage and water or wind erosion are applied. Aggregate stability is an indicator of organic matter content, biological activity, and nutrient cycling in soil. Generally, the particles in small aggregates $(<0.25 \mathrm{~mm})$ are bound by older and more stable forms of organic matter. Microbial decomposition of fresh organic matter releases products (that are less stable) that bind small aggregates into large aggregates (> 2-5 $\mathrm{mm}$ ). These large aggregates are more sensitive to management effects on organic matter, serving as a better indicator of changes in soil quality. Greater amounts of stable aggregates suggest better 
soil quality. When the proportion of large to small aggregates increases, soil quality generally increases.

Wright et al., (2007) reported that in the 0-5 $\mathrm{cm}$ soil depth, no-tillage increased macroaggregate associated $\mathrm{OC}$ as compared to conventional tillage. Macro-aggregates accounted for 38- 64, 48-66, and 54-71\% of the total soil mass in the $0-5,5-10$, and 10-20 $\mathrm{cm}$ soil depths, respectively. The corresponding proportions of the silt + clay fraction were 3-7, 2-6, and 1- 5\%, respectively. Proportions of macro-aggregates were increased with reduction of soil tillage frequency. For the $0-5 \mathrm{~cm}$ soil depth, treatments NT and 4T had significantly higher mass proportions of macro-aggregates (36 and $23 \%$, respectively) than that of treatment. With additions of crop residues, the amount of macro-aggregates increased in all tillage treatments. Naresh et al., (2015) also observed that macro-aggregates are less stable than micro-aggregates and more susceptible to the disruptive forces of tillage, and $>2 \mathrm{~mm}$ size macro-aggregates showed the lowest percentage distribution across depths. This might be attributed to the mechanical disruption of macro-aggregates with frequent tillage operations and reduced aggregate stability. The proportion of the microaggregates in all treatments was small and they had the lowest OC content. However, micro-aggregates formation and the microaggregates within the macro-aggregates can play an important role in $\mathrm{C}$ storage and stabilization in the long term (Kumari et al., 2011). Xue et al., (2015) also found that over time, CT generally exhibits a significant decline in SOC concentration due to destruction of the soil structure, exposing SOM protected within soil aggregates to microbial organisms. Thus, the adoption of no-till system can minimize the loss of SOC leading to higher or similar concentration compared to CT. Zhou et al., (2013) also found that, compared to CT, macro-aggregates in RT in wheat coupled with unpuddled transplanted rice (RT-TPR) was increased by $50.1 \%$ and micro-aggregates in RT-TPR decreased by $10.1 \%$ in surface soil. Surface residue retention $(50 \%)$ caused a significant increment of $15.7 \%$ in total aggregates in surface soil $(0-5 \mathrm{~cm})$ and $7.5 \%$ in subsurface soil $(5-10 \mathrm{~cm})$. In surface soil, $19.2 \%$ of total aggregate $\mathrm{C}$ was retained by $>2 \mathrm{~mm}$ and $8.9 \%$ by $0.1-0.05 \mathrm{~mm}$ size fractions. RT-TPR combined with $\mathrm{ZT}$ on permanent wide raised beds in wheat (with residue) had the highest capability to hold the OC in surface $(11.6 \mathrm{~g}$ $\mathrm{kg}^{-1}$ soil aggregates).

Zhou et al., (2013) concluded that the application of NPK plus OM increased the size of sub-aggregates that comprised the macro-aggregates. Also, they observed that long-term application of NPK plus OM improves soil aggregation and alters the threedimensional microstructure of macroaggregates, while NPK alone does not. Zhang et al., (2013) showed that NT and RT significantly increased the proportion of macro-aggregate fractions (> 2000 and 250 $2000 \mu \mathrm{m}$ ) compared with the moldboard plow without residue (MP-R) and moldboard plow with residue $(M P+R)$ treatments. Averaged across depths, MWD of aggregates in NT and RT were 47 and $20 \%$ higher than that in $\mathrm{MP}+\mathrm{R}$. Hati et al., (2014) revealed that the MWD of the top $15 \mathrm{~cm}$ soil under NT (1.05 $\mathrm{mm}$ ) was significantly higher than that under RT and MB (moldboard tillage) and the MWD was least under CT $(0.71 \mathrm{~mm})$. Similarly, $\%$ WSma was maximum under NT $(63.5 \%)$ and minimum under CT (50.2\%). Mamta Kumari et al., (2014) showed that the tillage induced changes in the intra-aggregate POM$\mathrm{C}$ content was distinguishable at $0-$ to $5-\mathrm{cm}$ depth. On average, the iPOM C content in soil was higher at wheat than at rice harvest, and accumulated in greater portion as fine $(0.053-$ $0.25 \mathrm{~mm})$ than the coarse $(0.25-2 \mathrm{~mm})$ fraction. A significantly higher particulate-C fraction was recorded in the zero-till systems 
( $\mathrm{T}_{5}$ and $\mathrm{T}_{6}$ ), and was associated more with the fine fractions $(20-30 \%$ higher than under conventional-tillage $\mathrm{T}_{1}$ and $\mathrm{T}_{2}$ ).

Ou et al., (2016) reported that in the 0.00-0.05 $\mathrm{m}$ layer, SOC concentration in macro aggregates showed the order of $\mathrm{NT}+\mathrm{S}>\mathrm{MP}+\mathrm{S}$ $=\mathrm{NT}-\mathrm{S}>\mathrm{MP}-\mathrm{S}$, whereas the NT system was superior to the MP system. However, the NT system significantly reduced the SOC concentration in the $2.00-0.25 \mathrm{~mm}$ fraction in the $0.05-0.20 \mathrm{~m}$ layer. A similar trend was observed in the $0.25-0.053 \mathrm{~mm}$ fraction in the $0.20-0.30 \mathrm{~m}$ layer. Across all the soil layers, there was no difference in the $<0.053 \mathrm{~mm}$ fraction between NT-S and MP-S, as well as between $\mathrm{NT}+\mathrm{S}$ and $\mathrm{MP}+\mathrm{S}$, indicating that the SOC concentration in Silt + Clay fraction. In average across the soil layers, the soil organic carbon concentration in the macro aggregates was increased by $13.5 \%$ in $\mathrm{MP}+\mathrm{S}, 4.4 \%$ in ST-S and $19.3 \%$ in $\mathrm{NT}+\mathrm{S}$, and those the micro aggregates $(<0.25 \mathrm{~mm})$ were increased by $6.1 \%$ in $\mathrm{MP}+\mathrm{S}$ and $7.0 \%$ in $\mathrm{NT}+\mathrm{S}$ compared to MP-S. For all the soil layers, the SOC concentration in all the aggregate size classes was increased with straw incorporation by 20.0, 3.8 and 5.7\% under the MP system and 20.2, 6.3 and $8.8 \%$ under NT system.

Song et al., (2016) showed that the mean percentages of $>2 \mathrm{~mm}$ macro-aggregates and water-stable macro-aggregates were increased by $12.77 \%$ and $43.21 \%$, respectively, for the treatment group of rice-wheat under zero tillage compared to rice- wheat conventional tillage. In the $0-15 \mathrm{~cm}$ and $15-30 \mathrm{~cm}$ soil layers, the percentage of $2-0.25 \mathrm{~mm}$ waterstable macro-aggregates was increased by $25 \%$ and $40 \%$, respectively, for the Rice Wheat zero tillage treatment compared to the Rice Wheat conventional tillage treatment. Thus, compared to conventional tillage, zero tillage can reduce the turnover of macroaggregates in farmland and facilitate the enclosure of organic carbon in micro- aggregates, which enables micro-aggregates to preserve more physically protected organic carbon and form more macro-aggregates. Moreover, results showed that zero tillage resulted in higher organic carbon storage in soil aggregates in the $0-15 \mathrm{~cm}$ soil layer than conventional tillage primarily because conservation tillage reduces the damage to soil aggregates and increase the content and stability of associated organic carbon accordingly. The highest SOC concentration was found for the $0.25-0.106 \mathrm{~mm}$ microaggregates in the $0-15 \mathrm{~cm}$ and $15-30 \mathrm{~cm}$ soil layers. Simansky et al., (2017) reported that the soil-management practices significantly influenced the soil organic carbon in waterstable aggregates (SOC in WSA). The content of SOC in WSA ma increased on average in the following order: $\quad \mathrm{T}<\mathrm{G}<$ $\mathrm{G}+\mathrm{NPK}_{1}<\mathrm{G}+\mathrm{NPK}_{3}<\mathrm{T}+\mathrm{FYM}$. Intensive soil cultivation in the $\mathrm{T}$ treatment resulted in a statistically significant build-up of SOC in WSA ma at an average rate of $1.33,1.18$, $0.97,1.22$ and $0.76 \mathrm{gkg}^{-1} \mathrm{yr}^{-1}$ across the size fractions $>5 \mathrm{~mm}, 5-3 \mathrm{~mm}, 2-1 \mathrm{~mm}, 1-0.5$ $\mathrm{mm}$ and $0.5-0.25 \mathrm{~mm}$, respectively.

\section{Soil organic carbon fractions}

Soil organic carbon (SOC) consists of various fractions varying in degree of decomposition, recalcitrance and turnover rates (Huang et al., 2008). The SOC fractions can be classified as labile, semi labile and recalcitrant. These fractions exhibit different rates of biochemical and microbial degradation (Stevenson, 1994) as well as different sensitivity to changes in different environmental conditions. Presence of different SOC fractions in soil reflect key processes of nutrient cycling and availability, soil aggregation and stability and soil carbon accrual (Wander, 2004). Sheng et al., (2015) observed that the stocks associated with the different LOC fractions in topsoil and subsoil responded differently to land use changes. POC decreased by $15 \%, 38 \%$, and $33 \%$ at 0 - 
$20 \mathrm{~cm}$ depth, and by $10 \%, 12 \%$, and $18 \%$ at $20 \mathrm{e} 100 \mathrm{~cm}$ depth following natural forest conversion to plantation, orchard, and sloping tillage, respectively. POC stock in topsoil was more sensitive to land use change than that in subsoil. Regarding the different POC components, only fPOC stock in $0-20 \mathrm{~cm}$ topsoil decreased by $21 \%, 53 \%$, and $51 \%$ after natural forest conversion to plantation, orchard, and sloping tillage, respectively. Significant loss of LFOC occurred not only in topsoil, but also in subsoil below $20 \mathrm{~cm}$ following land use change. The decrease in ROC stock through the soil depth profile following land use change was smaller than that of LFOC. ROC stocks did not differ significantly between natural forest and sloping tillage areas, suggesting that ROC stock was relatively insensitive to land use change. The DOC stock in the topsoil decreased by $29 \%$ and $78 \%$ following the conversion of natural forest to plantation and orchard, respectively, and subsoil DOC stocks decreased even more dramatically following land use change. The proportion of the different LOC pools in relation to SOC can be used to detect changes in SOC quality. In the topsoil, the ratios $\mathrm{PPOC}$, LFOC, and MBC to SOC decreased, while those of ROC and cPOC increased following land use change. In subsoil, only the ratio of DOC to SOC decreased, the ratios POC, FPOC and ROC to SOC increased, and those of LFOC and MBC remained constant following land use change. In the topsoil, ratios fPOC, LFOC, DOC and $\mathrm{MBC}$ to SOC were more sensitive to conversion from natural forest to sloping tillage than SOC.

Zhu et al., (2015) revealed that the soil total organic $\mathrm{C}$ (TOC) and labile organic $\mathrm{C}$ fraction contents were higher under the straw return treatments compared to the no straw return treatment $(0 \% \mathrm{~S})$ at a $0-21$ soil depth. The $50 \%$ annual straw return rate $(50 \% \mathrm{~S})$ had significantly higher soil TOC, dissolved organic C (DOC), and easily oxidizable C (EOC) contents than the $0 \% \mathrm{~S}$ treatment at a $0-21 \mathrm{~cm}$ depth. All of the straw return treatments had a significantly higher DOC content than the $0 \% \mathrm{~S}$ treatment at a $0-21 \mathrm{~cm}$ depth, except for the $100 \%$ only rice straw return treatment (100\% RS). Wang et al., (2015) also found that in the early paddy field, the average values of the total SOC, LFOC, and DOC concentration in the top $40 \mathrm{~cm}$ soil were significantly higher in the straw application plots than in the controls, by $7.2 \%$ $8.8 \%$ and $15.6 \%$, respectively. Naresh et al., (2017) reported that the $T_{3}$ treatment resulted in significantly increased $66.1 \%, 50.9 \%$, $38.3 \%$ and $32 \%$ LFOC, PON, LFON and $\mathrm{POC}$, over $\mathrm{T}_{7}$ treatment and WSC $39.6 \%$ in surface soil and $37.4 \%$ in subsurface soil. LFOC were also significantly higher following the treatments including organic amendment than following applications solely of chemical fertilizers, except that the $\mathrm{F}_{5}, \mathrm{~F}_{6}$ and $\mathrm{F}_{7}$ treatments resulted in similar LFOC contents. Application solely of chemical fertilizers had no significant effects on LFOC compared with unfertilized control plots. Nevertheless, application of $\mathrm{F}_{5}$ or $\mathrm{F}_{6}$ significantly increased contents of POC relative to $\mathrm{F} 1$ (by $49.6 \%$ and $63.4 \%$, respectively).

Kumar et al., (2018) also found that the ZTR (zero till with residue retention) $\left(\mathrm{T}_{1}\right)$ and RTR (Reduced till with residue retention) $\left(\mathrm{T}_{3}\right)$ showed significantly higher BC, WSOC, SOC and OC content of $24.5 \%, 21.9 \%, 19.37$ and $18.34 \mathrm{gkg}^{-1}$, respectively as compared to the other treatments. Irrespective of residue retention, wheat sown in zero till plots enhanced $22.7 \%, 15.7 \%, 36.9 \%$ and $28.8 \%$ of $\mathrm{BC}$, WSOC, SOC and OC, respectively, in surface soil as compared to conventional tillage. Simultaneously, residue retention in zero tillage caused an increment of $22.3 \%$, $14.0 \%, 24.1 \%$ and $19.4 \%$ in BC, WSOC, SOC and $\mathrm{OC}$, respectively over the treatments with 
no residue management. Similar increasing trends of conservation practices on different forms of carbon under sub-surface $(15-30 \mathrm{~cm})$ soil were observed however, the magnitude was relatively lower. However, the $0-15$ and 15-30 cm, POC, PON, LFOC and LFON content under $\mathrm{ZT}$ and $\mathrm{RT}$ with residue retention was greater than under without residue and conventional sown plots, respectively. The decrease in the disruption of soil macro-aggregates under ZT plots permitted a greater accumulation of SOC between and within the aggregates. Thus less soil disturbance is the major cause of higher POC in the ZT and RT plots compared with the CT plots in the $0-15 \mathrm{~cm}$ and $15-30 \mathrm{~cm}$ soil layers. This phenomenon might lead to microaggregate formation within macro-aggregates formed around fine intra-aggregate POC and to a long-term stabilization of SOC occluded within these micro-aggregates. The sequestration rate of POC, PON, LFOC and LFON in all the treatments followed the order $200 \mathrm{~kg} \mathrm{Nha}^{-1}\left(\mathrm{~F}_{4}\right) 160 \mathrm{~kg} \mathrm{Nha}^{-1}\left(\mathrm{~F}_{3}\right)>120 \mathrm{~kg}$ $\mathrm{Nha}^{-1}\left(\mathrm{~F}_{2}\right)>800 \quad \mathrm{~kg}$ Nha $-1\left(\mathrm{~F}_{1}\right)>$ control (unfertilized) (F0). Kashif et al., (2019) also found that the particulate organic carbon (POC), easily oxidizable carbon (EOC), dissolved organic carbon (DOC) contents of 0-20 cm depth were 80, 22 and $13 \%$, respectively, higher under no-tillage with straw returning (NTS) treatment.

Soil organic carbon, soil aggregation vis-àvis soil organic fractions

Soil aggregation results from the rearrangement of particles, flocculation and cementation. In binding soil particles together, the SOC and its fractions play a great role as the gluing agent. There exists a closer interaction between SOC concentration and soil aggregation due to the binding action of humic substances and other microbial byproducts on soil particles (Shepherd et al., 2001). The SOC promotes soil aggregation, whereas aggregates in return store SOC, reducing the rate of SOM decomposition.

Since soil aggregation and stability of aggregates is a function of SOC and its fractions, their concentration and stock are of paramount importance in determining the formation and stabilization of soil aggregates (Debasish et al., 2011). Keeping in view the role played by SOC and its fraction as a binding agent, variation of its content as a result of land use change may strongly affect the process of soil aggregation.

Mangalassery et al., (2014) revealed that zero tilled soils contained significantly more soil organic matter (SOM) than tilled soils. Soil from the $0-10 \mathrm{~cm}$ layer contained more SOM than soils from the 10-20 cm layers in both zero tilled $(7.8$ and $7.4 \%$ at $0-10 \mathrm{~cm}$ and $10-$ $20 \mathrm{~cm}$ respectively) and tilled soils $(6.6 \%$ at $0-10 \mathrm{~cm}$ and $6.2 \%$ at $10-20 \mathrm{~cm})$. Wang et al.,(2018) reported that tillage system change influenced SOC content, NT, ST, and BT showed higher values of SOC content and increased 8.34, 7.83, and $1.64 \mathrm{Mg} \cdot \mathrm{C} \cdot \mathrm{ha}^{-1}$, respectively, compared with CT. Among the 3 changed tillage systems, NT and ST showed a $12.5 \%$ and $11.6 \%$ increase in SOC content then BT, respectively. Tillage system change influenced SOC stratification ratio values, with higher value observed in BT and NT compared CT but ST. Therefore, in loess soil, changing tillage system can significantly improve SOC storage and change profile distribution. Moussadek et al., (2014) observed that the SOCs was significantly higher in NT compared to CT (10\% more in Vertisol), but no significant difference was observed in the Luvisol. Average SOCs within the $0-30 \mathrm{~cm}$ depth was 29.35 and $27.36 \mathrm{Mg}$ $\mathrm{ha}^{-1}$ under NT and CT, respectively. The highest SOCs $\left(31.89 \mathrm{Mg} \mathrm{ha}^{-1}\right.$ ) were found in Vertisols under NT.

Chu et al., (2016) revealed that cropping system increased the stocks of $\mathrm{OC}$ and $\mathrm{N}$ in 
total soils at mean rates of $13.2 \mathrm{~g} \mathrm{OC} \mathrm{m}^{-2} \mathrm{yr}^{-1}$ and $0.8 \mathrm{~g} \mathrm{~N} \mathrm{~m}^{-2} \mathrm{yr}^{-1}$ at the $0-20 \mathrm{~cm}^{-2}$ depth and of $2.4 \mathrm{~g} \mathrm{OC} \mathrm{m}^{-2} \mathrm{yr}^{-1}$ and $0.4 \mathrm{~g} \mathrm{~N} \mathrm{~m}^{-2} \mathrm{yr}^{-1}$ at the $20-40 \mathrm{~cm}$ depth. The stocks of OC and $\mathrm{N}$ in this system increased by 45 and $36 \%$, respectively, (with recovery rates of $31.1 \mathrm{OC}$ $\mathrm{m}^{-2} \mathrm{yr}^{-1}$ and $\left.2.4 \mathrm{~g} \mathrm{~N} \mathrm{~m}^{-2} \mathrm{yr}^{-1}\right)$ at the $0-20 \mathrm{~cm}$ depth and by 5 and $6 \%$, (with recovery rates of $3.0 \mathrm{OC} \mathrm{m}^{-2} \mathrm{yr}^{-1}$ and $0.03 \mathrm{~g} \mathrm{~N} \mathrm{~m}^{-2} \mathrm{yr}^{-1}$ ) at the 20-40 cm depth. Das et al., (2017) revealed that the total organic $\mathrm{C}$ increased significantly with the integrated use of fertilizers and organic sources (from 13 to $16.03 \mathrm{~g} \mathrm{~kg}^{-1}$ ) compared with unfertilized control $\left(11.5 \mathrm{gkg}^{-}\right.$ ${ }^{1}$ ) or sole fertilizer (NPKZn; $12.17 \mathrm{~g} \mathrm{~kg}^{-1}$ ) treatment at $0-7.5 \mathrm{~cm}$ soil depth. Dhaliwal et al., (2018) revealed that the mean SOC concentration decreased with the dry stable aggregates (DSA) and water stable aggregates (WSA). In DSA, the mean SOC concentration was 58.06 and $24.2 \%$ higher in large and small macro-aggregates than in micro-aggregates respectively; in WSA it was 295.6 and $226.08 \%$ higher in large and small macroaggregates than in micro-aggregates respectively in surface soil layer. The mean SOC concentration in surface soil was higher in DSA $(0.79 \%)$ and WSA $(0.63 \%)$ as compared to bulk soil $(0.52 \%)$.

Krishna et al., (2018) reported that the total organic carbon (TOC) allocated into different pools in order of very labile $>$ less labile $>$ non labile >labile, constituting about 41.4, 20.6, 19.3 and $18.7 \%$, respectively. In comparison with control, system receiving farmyard manure (FYM-10 Mgha $^{-1}$ season $^{-1}$ ) alone showed greater $\mathrm{C}$ build up (40.5\%) followed by $100 \%$ NPK+FYM (120:60:40 kg N, P, K $\mathrm{ha}^{-1}+5 \mathrm{Mg} \mathrm{FYM} \mathrm{ha}^{-1}$ season $^{-1}$ ) (16.2\%). In fact, a net depletion of carbon stock was observed with $50 \%$ NPK (-1.2 $\left.\mathrm{Mg} \mathrm{ha}^{-1}\right)$ and control ($1.8 \mathrm{Mg} \mathrm{ha}^{-1}$ ) treatments. Only $28.9 \%$ of $\mathrm{C}$ applied through FYM was stabilized as SOC. A minimal input of $2.34 \mathrm{Mg} \mathrm{C} \mathrm{ha}^{-1} \mathrm{yr}^{-1}$ is needed to maintain SOC level. Naresh et al., (2018) reported that conservation tillage practices significantly influenced the total soil carbon (TC), Total inorganic carbon (TIC), total soil organic carbon (SOC) and oxidizable organic carbon (OC) content of the surface $(0-$ $15 \mathrm{~cm}$ ) soil. Wide raised beds transplanted rice and zero till wheat with $100 \%\left(\mathrm{~T}_{9}\right)$ or with $50 \%$ residue management $\left(\mathrm{T}_{8}\right)$ showed significantly higher TC, SOC content of 11.93 and $10.73 \mathrm{~g} \mathrm{~kg}^{-1}$,respectively in $\mathrm{T}_{9}$ and 10.98 and $9.38 \mathrm{~g} \mathrm{~kg}^{-1}$, respectively in $\mathrm{T}_{8}$ as compared to the other treatments. Irrespective of residue incorporation/ retention, wide raised beds with zero till wheat enhanced $53.6 \%$, $33.3 \%, 38.7 \%$ and $41.9 \%$ of TC, TIC, SOC and OC, respectively, in surface soil as compared to conventional tillage with transplanted rice cultivation. Simultaneously, residue retention caused an increment of $6.4 \%$, $7.4 \%, 8.7 \%$ and $10.6 \%$ in TC, TIC, SOC and OC, respectively over the treatments without residue management. Concerning the organic carbon storage, SOCs varied between $31.9 \mathrm{Mg} \cdot \mathrm{ha}^{-1}$ and $25.8 \mathrm{Mg} \cdot \mathrm{ha}^{-1}$ under $\mathrm{NT}$, while, in tilled treatments, SOCs ranged between $28.8 \mathrm{Mg} \cdot \mathrm{ha}^{-1}$ and $24.8 \mathrm{Mg} \cdot \mathrm{ha}^{-1}$. These values were lower than those observed by Fernández-Ugalde et al., (2009) who found, in silty clay soil, a SOCs at $0-30 \mathrm{~cm}$ of $50.9 \mathrm{Mg} \cdot \mathrm{ha}^{-1}$ after 7 years of no tillage, which was significantly higher than the $44.1 \mathrm{Mg} \cdot \mathrm{ha}^{-1}$ under CT under wheat-barley cropping system in semiarid area.

Xu et al., (2013) observed that the SOC stocks in the $0-80 \mathrm{~cm}$ layer under NT was as high as 129.32 Mg C ha ${ }^{-1}$, significantly higher than those under PT and RT. The order of SOC stocks in the $0-80 \mathrm{~cm}$ soil layer was NT > PT $>\mathrm{RT}$, and the same order was observed for SCB; however, in the $0-20 \mathrm{~cm}$ soil layer, the RT treatment had a higher SOC stock than the PT treatment. Alemayehu et al., (2016) also found that the carbon storage per hectare for the four soil textures at 0 to $15 \mathrm{~cm}$ depth were $68.4,63.7,38.1$ and 31.3 tha $^{-1}$ for sandy loam, silt loam, loam and clay loam; respectively. Sand and silt loams had nearly twice the 
organic carbon content than loam and clay loam soil. The soil organic carbon content for tillage type at 0 to $15 \mathrm{~cm}$ was $8.6,10.6,11.8$ and $19.8 \mathrm{~g} \mathrm{~kg}^{-1}$ for deep significant accumulation at $0-20 \mathrm{~cm}$ depth.

Zheng et al., (2018) reported that across treatments, aggregate-associated $\mathrm{C}$ at a depth of $0-10 \mathrm{~cm}$ was higher in the NT and ST treatments than in the MP and CT treatments. The advantage of the NT treatment weakened with soil depth, while the amount of aggregate-associated $\mathrm{C}$ remained higher for the ST treatment. There were more macroaggregates in the ST and NT treatments than in the MP and CT treatments, while the MP and CT treatments had more microaggregates. The sum of macro-aggregate contributing rates for soil organic C (SOC) was significantly superior to that of the microaggregates. Mahajan et al., (2019) reported that the increased SOC stock in the surface 50 $\mathrm{kg} \mathrm{m}^{-2}$ under ZT and PRB was compensated by greater SOC stocks in the 50-200 and 200$400 \mathrm{~kg} \mathrm{~m}^{-2}$ interval under residue retained, but SOC stocks under CT were consistently lower in the surface $400 \mathrm{~kg} \mathrm{~m}^{-2}$.Soil organic carbon fractions (SOC), microbial biomasses and enzyme activities in the macro-aggregates are more sensitive to conservation tillage (CT) than in the micro-aggregates. Responses of macro-aggregates to straw return showed positively linear with increasing SOC concentration. Straw-C input rate and clay content significantly affected the response of SOC.

\section{Particulate organic matter}

Particulate organic matter (POM) is readily decomposable, serving many soil functions and providing terrestrial material to water bodies. It is a source of food for both soil organisms and aquatic organisms (see below), and provides nutrients for plants. In water bodies, POM can contribute substantially to turbidity, limiting photic depth which can suppress primary productivity. POM also enhances soil structure leading to increased water infiltration, aeration and resistance to erosion. Soil management practices, such as tillage and compost/ manure application, alter the POM content of soil and water. Coarse particulate organic matter, or CPOM, in streams is functionally defined as any organic particle larger than 1 $\mathrm{mm}$ in size (Cummins, 1974). Regardless of source, this CPOM is broken down by stream biota during an activity known as organic matter processing. Organic particles in the size range of $>0.45$ to $<1000 \mu \mathrm{m}$ that are either suspended in the water column or deposited within lotic habitats are considered as fine particulate organic matter or FPOM. FPOM also varies in quality, often as a product of its source.

Liu et al., (2013) revealed that the particulate organic $\mathrm{C}$ was found stratified along the soil depth. A higher POC was found in surface soil decreasing with depth. At the $0-20 \mathrm{~cm}, \mathrm{POC}$ content under $\mathrm{NP}+\mathrm{FYM}, \mathrm{NP}+\mathrm{S}$ and $\mathrm{FYM}$ were 103,89 and $90 \%$ greater than under CK, respectively. In $20-40 \mathrm{~cm}$ and $40-60 \mathrm{~cm}$ soil layers, NP+FYM had maximum POC which was significantly higher than $\mathrm{NP}+\mathrm{S}$ and $\mathrm{FYM}$ treatments. Even though POC below $60 \mathrm{~cm}$ depth was statistically similar among fertilization treatments, the general trend was for increased POC with farmyard manure or straw application down to $100 \mathrm{~cm}$ soil depth. Irrespective of soil depths, NP+FYM invariably showed higher content of DOC over all other treatments. The $\mathrm{CK}$ and $\mathrm{N}$ treatments showed lower content of DOC. The DOC concentrations in $0-20 \mathrm{~cm}, 20-40 \mathrm{~cm}$ and $40-60 \mathrm{~cm}$ depths were observed highest for NP+FYM followed by NP+S and FYM, and both of them were significant higher than NP. However, in the deeper layers $(60-80 \mathrm{~cm}$ and $80-100 \mathrm{~cm}$ ), the difference in DOC among the treatments was not significant. 
Naresh et al., (2016) also found significantly higher POC content was probably also due to higher biomass $\mathrm{C}$. Results on PON content after 3-year showed that in $0-5 \mathrm{~cm}$ soil layer of CT system, $\mathrm{T}_{1}$, and $\mathrm{T}_{5}$ treatments increased PON content from $35.8 \mathrm{mgkg}^{-1}$ in $\mathrm{CT}\left(\mathrm{T}_{9}\right)$ to 47.3 and $67.7 \mathrm{mg} \cdot \mathrm{kg}^{-1}$ without $\mathrm{CR}$, and to 78.3, 92.4 and $103.8 \mathrm{mgkg}^{-1}$ with CR @ 2, 4 and 6 tha $^{-1}$, respectively. The corresponding increase of PON content under CA system was from $35.9 \mathrm{mgkg}^{-1}$ in CT system to 49 and $69.6 \mathrm{mgkg}^{-1}$ without $\mathrm{CR}$ and 79.3, 93.0 and $104.3 \mathrm{mgkg}^{-1}$ with CR @ 2, 4 and 6tha ${ }^{-1}$, respectively. Juan et al., (2018) observed that the pure organic manure treatments (DMA and SMA) showed significantly higher concentrations of POC as compared to integrate $(1 / 2 \mathrm{SMF}+1 / 2 \mathrm{SMA})$ and mineralfertilized plots (DMF and SMF). POC constituted 10.20 to $23.65 \%$ of total SOC with a mean value of $16.43 \%$. Highest proportion of POC was observed under DMA, followed by SMA, which was not significantly different from DMF; $1 / 2 \mathrm{SMF}+1 / 2 \mathrm{SMA}$ and SMF had a lower proportion of POC and the lowest proportion was found in the $\mathrm{CK}$ treatment.

\section{Microbial biomass carbon}

Kushwaha et al., (2000) observed that the highest levels of soil MBC and MBN (368503 and $38.2-59.7 \mu \mathrm{g} \mathrm{g}^{-1}$, respectively) were obtained in minimum tillage residue retained (MT+R) treatment and lowest levels (214-264 and $20.3-27.1 \mu \mathrm{g} \mathrm{g}^{-1}$, respectively) in conventional tillage residue removed (CT-R, control) treatment. Along with residue tillage reduction from conventional to zero increased the levels of MBC and MBN (36-82 and 29$104 \%$ over control, respectively. This increase (28\% in of $\mathrm{C}$ and $33 \% \mathrm{~N}$ ) was maximum in $\mathrm{MT}+\mathrm{R}$ and minimum (10\% for $\mathrm{C}$ and $\mathrm{N}$ both) in minimum tillage residue removed (MT-R) treatment. In all treatments concentrations of $\mathrm{N}$ in microbial biomass were greater at seedling stage, thereafter these concentrations decreased drastically $(21-38 \%)$ at grain forming stage of both crops. In residue removed treatments, $\mathrm{N}$-mineralization rates were maximum during the seedling stage of crops and then decreased through the crop maturity. The increase in the level of MBC from the seedling to grain-forming stage of crops was probably a result of increased $\mathrm{C}$ input from the rhizosphere products to the soil before and during flowering. Dou et al., (2008) reported that SMBC was 5 to $8 \%$, mineralized $\mathrm{C}$ was $2 \%$, POM C was 14 to $31 \%$, hydrolyzable $\mathrm{C}$ was 53 to $71 \%$, and DOC was 1 to $2 \%$ of SOC. No-till significantly increased SMBC in the 0- to 30$\mathrm{cm}$ depth, especially in the surface 0 to $5 \mathrm{~cm}$. Under NT, SMBC at 0 to $5 \mathrm{~cm}$ was 25,33 , and $22 \%$ greater for CW, SWS, and WS, respectively, than under $\mathrm{CT}$, but was 20 and $8 \%$ lower for CW and WS, respectively, than under CT at the 5- to $15-\mathrm{cm}$ depth. At the 15to $30-\mathrm{cm}$ depth, no consistent effect of tillage was observed. Enhanced cropping intensity increased SMBC only under NT, where SMBC was 31 and $36 \%$ greater for SWS and WS than $\mathrm{CW}$ at 0 to $30 \mathrm{~cm}$.

Jiang et al., (2011) observed that the highest levels of MBC were associated with the 1.0$2.0 \mathrm{~mm}$ aggregate size class (1025 and $805 \mathrm{mg}$ $\mathrm{C} \mathrm{kg}^{-1}$ for RNT and CT, respectively) which may imply that RNT was the ideal enhancer of soil productivity for this subtropical rice ecosystem. However, the lowest in the $<0.053$ mm fraction (390 and $251 \mathrm{mg} \mathrm{Ckg}^{-1}$ for RNT and $\mathrm{CT}$ respectively). It is interesting to note the sudden decrease of MBC values in 1-0.25 $\mathrm{mm}$ aggregates (511 and $353 \mathrm{mg} \mathrm{C} \mathrm{kg}^{-1}$ for RNT and CT, respectively) [Fig.8b].The highest values corresponded to the largest aggregates, N4.76 mm, (6.8 and $5.4 \%$ for RNT and CT, respectively) and the lowest to the aggregate size of $1.0-0.25 \mathrm{~mm}$ (1.6 and 1.7 for RNT and CT, respectively). Liang et al., (2011) observed that in the $0-10 \mathrm{~cm}$ soil layer, SMBC and SMBN in the three fertilized treatments were higher than in the unfertilized treatment on all sampling dates, while 
microbial biomass $\mathrm{C}$ and $\mathrm{N}$ in the $0-10 \mathrm{~cm}$ soil layers were the highest at grain filling. In the same soil layer, soil-soluble organic C generally decreased in the order MNPK > $\mathrm{SNPK}>\mathrm{NPK}>\mathrm{CK}$, while soluble organic N was the highest in the MNPK followed by the SNPK treatment. There was no significant difference in soluble organic $\mathrm{N}$ in the NPK and $\mathrm{CK}$ treatments throughout most of the maize growing season. Changes in soluble organic $\mathrm{N}$ occurred along the growing season and were more significant than those for soluble organic C. Soluble organic $\mathrm{N}$ was the highest at grain filling and the lowest at harvest. Overall, microbial biomass and soluble organic $\mathrm{N}$ in the surface soil were generally the highest at grain filling when maize growth was most vigorous.

Aulakh et al., (2013) showed that PMN content after 2 years of the experiment in 0-5 $\mathrm{cm}$ soil layer of CT system, $\mathrm{T}_{2}, \mathrm{~T}_{3}$ and $\mathrm{T}_{4}$ treatments increased PMN content from 2.7 $\mathrm{mgkg}^{-1} 7 \mathrm{~d}^{-1}$ in control $\left(\mathrm{T}_{1}\right)$ to $2.9,3.9$ and 5.1 $\mathrm{mgkg}^{-1} 7 \mathrm{~d}^{-1}$ without $\mathrm{CR}$, and to $6.9,8.4$ and $9.7 \mathrm{mg} \mathrm{kg}^{-1} 7 \mathrm{~d}^{-1}$ with $\mathrm{CR}\left(\mathrm{T}_{6}, \mathrm{~T}_{7}\right.$ and $\left.\mathrm{T}_{8}\right)$, respectively. The corresponding increase of PMN content under CA system was from 3.6 $\mathrm{mgkg}^{-1} 7 \mathrm{~d}^{-1}$ in control to $3.9,5.1$ and 6.5 $\mathrm{mgkg}^{-1} 7 \mathrm{~d}^{-1}$ without $\mathrm{CR}$ and to $8.9,10.3$ and $12.1 \mathrm{mgkg}^{-1} 7 \mathrm{~d}^{-1}$ with CR. PMN, a measure of the soil capacity to supply mineral $\mathrm{N}$, constitutes an important measure of the soil health due to its strong relationship with the capability of soil to supply $\mathrm{N}$ for crop growth. Bhattacharya et al., (2013) reported that tillage-induced changes in POM C were distinguishable only in the 0 - to $5-\mathrm{cm}$ soil layer; the differences were insignificant in the 5- to $15-\mathrm{cm}$ soil layer. Plots under ZT had about 14\% higher POM C than CT plots (3.61 $\mathrm{g} \mathrm{kg}^{-1}$ bulk soil) in the surface soil layer.

Mandal et al., (2013) reported that averaged across fertilization and manure treatments, MBC varied significantly with soil depth, with mean values of 239,189 and $127 \mathrm{mg} \mathrm{kg}^{-1}$ at $0_{-}$
7.5, 7.5-15 and 15-30 cm depths respectively. Surface soil had higher MBC than deeper soil layers, due primarily to the addition of leftover CRs and root biomass to the topsoil. When averaged across soil depths, the MBC content under the different treatments was in the order: $\mathrm{NPK}+\mathrm{GR}+\mathrm{FYM}>\mathrm{NPK}+\mathrm{FYM}=\mathrm{NPK}$ $+\mathrm{GR}>\mathrm{NPK}+\mathrm{SPM}>\mathrm{NPK}+\mathrm{CR}>\mathrm{PKZnS}>$ $\mathrm{NPKZn}=$ control. Incorporation of $\mathrm{CR}$ slows mineralization processes; hence, microbes take longer to decompose the residue and use the released nutrients. Conversely, incorporation of GR, with a narrow $\mathrm{C}$ : $\mathrm{N}$ ratio, hastened mineralization by enhancing microbial activity in the soil.

Tripathi et al., (2014) observed that the significant positive correlations were observed between TOC and organic $\mathrm{C}$ fractions (POC and $\mathrm{SMBC}$ ), illustrating a close relationship between TOC and POC and TOC and SMBC and that SOC is a major determinant of POC and SMBC. The microbial biomass carbon includes living microbial bodies (bacteria, fungi, soil fauna and algae) (Divya et al., 2014); it is more sensitive to soil disturbance than TOC. The proportion of SMBC to TOC is evaluation of carbon availability indexes for agriculture soil, which is usually $0.5-4.6 \%$. Liu et al., (2012) showed that SMBC may provide a more sensitive appraisal and an indication of the effects of tillage and residue management practices on TOC concentrations. Ma et al., (2016) reported that the differences in SMBC were limited to the surface layers (0-5 and 5-10 cm) in the PRB treatment. There was a significant reduction in SMBC content with depth in all treatments. SMBC in the PRB treatment increased by $19.8 \%$, $26.2 \%, 10.3 \%, 27.7 \%, 10 \%$ and $9 \%$ at $0-5,5-$ 10,10-20, 20-40,40-60 and 60-90 cm depths, respectively, when compared with the TT treatment. The mean SMBC of the PRB treatment was $14 \%$ higher than that in the TT treatment. Malviya, (2014) also indicated that irrespective of soil depth the SMBC contents were significantly higher under RT over CT. 
This was attributed to residue addition increases microbial biomass due to increase in carbon substrate under RT. Spedding et al., (2004) found that residue management had more influence than tillage system on microbial characteristics, and higher SMB-C and $\mathrm{N}$ levels were found in plots with residue retention than with residue removal, although the differences were significant only in the 0$10 \mathrm{~cm}$ layer.

Mangalassery et al., (2014) observed that zero tilled soils contained significantly more microbial biomass carbon than tilled soils. The mean microbial biomass carbon under zero tilled soil was $517.0 \mathrm{mg} \mathrm{kg}^{-1}$ soil compared with $418.7 \mathrm{mg} \mathrm{kg}^{-1}$ soil in tilled soils. Microbial biomass carbon was significantly higher in the $0-10 \mathrm{~cm}$ layer $\left(517 \mathrm{mg} \mathrm{kg}^{-1}\right.$ soil) than the $10-20 \mathrm{~cm}$ layer (419 $\mathrm{mg} \mathrm{kg}^{-1}$ soil) under zero tillage and conventional tillage. Moreover, tillage and soil depth significantly influenced soil microbial biomass nitrogen. Zero tilled soils contained higher microbial biomass nitrogen (91.1 $\mathrm{mg} \mathrm{kg}^{-1}$ soil) than tilled soil $\left(70.0 \mathrm{mg} \mathrm{kg}^{-1}\right.$ soil). Surface layers $(0-10 \mathrm{~cm})$ maintained more microbial biomass nitrogen than sub surface layers $(10-20 \mathrm{~cm})$ under both zero tilled soils and tilled soils. $\mathrm{Gu}$ et al., (2016) reported that as compared with CT treatments, NT treatments increased MBC by $11.2 \%, 11.5 \%$, and $20 \%$, and dissolved organic carbon (DOC) concentration by $15.5 \%, 29.5 \%$, and $14.1 \%$ of bulk soil, $>0.25 \mathrm{~mm}$ aggregate, and $<0.25 \mathrm{~mm}$ aggregate in the $0-5 \mathrm{~cm}$ soil layer, respectively. Compared with NS treatments, S treatments significantly increased $\mathrm{MBC}$ by $29.8 \%$, $30.2 \%$, and $24.1 \%$, and DOC concentration by $23.2 \%, 25.0 \%$, and $37.5 \%$ of bulk soil, $>0.25$ $\mathrm{mm}$ aggregate, and $<0.25 \mathrm{~mm}$ aggregate in the $0-5 \mathrm{~cm}$ soil layer, respectively. Conservation tillage (NT and S) increased microbial metabolic activities and Shannon index in $>0.25$ and $<0.25 \mathrm{~mm}$ aggregates in the $0-5 \mathrm{~cm}$ soil layer. Ma et al., (2016) reported that the differences in SMBC were limited to the surface layers $(0-5$ and $5-10 \mathrm{~cm})$ in the PRB treatment. There was a significant reduction in SMBC content with depth in all treatments. SMBC in the PRB treatment increased by $19.8 \%, 26.2 \%, 10.3 \%, 27.7 \%, 10 \%$ and $9 \%$ at $0-5,5-10,10-20,20-40,40-60$ and $60-90$ $\mathrm{cm}$ depths, respectively, when compared with the TT treatment. The mean SMBC of the PRB treatment was $14 \%$ higher than that in the TT treatment.

McGonigle and Turner (2017) concluded that the MBC in cropland increased from $210 \mu \mathrm{g} \mathrm{g}^{-}$ ${ }^{1}$ at $15 \mathrm{~g} \mathrm{~kg}^{-1}$ SOC to only $530 \mu \mathrm{g} \mathrm{g}^{-1}$ at $45 \mathrm{~g}$ $\mathrm{kg}^{-1}$ SOC. In contrast, $\mathrm{MBC}$ in grassland increased from $440 \mu \mathrm{g} \mathrm{g}^{-1}$ at $15 \mathrm{~g} \mathrm{~kg}^{-1} \mathrm{SOC}$ to $1190 \mu \mathrm{g} \mathrm{g}^{-1}$ at $45 \mathrm{~g} \mathrm{~kg}^{-1}$, thereafter increasing further to $1800 \mu \mathrm{g} \mathrm{g}^{-1}$ at $65 \mathrm{~g} \mathrm{~kg}^{-1} \mathrm{SOC}$. The slope of increase of $\mathrm{MBC}$ in response to increasing SOC was 2.5-fold higher in grassland at $27.2\left(\mu \mathrm{g} \mathrm{g}^{-1}\right) /\left(\mathrm{g} \mathrm{kg}^{-1}\right)$ compared to $10.7\left(\mu \mathrm{g} \mathrm{g}^{-1}\right) /\left(\mathrm{g} \mathrm{kg}^{-1}\right)$ for cropland. Maharjan et al., (2017) observed that the activity of $\beta$ glucosidase was higher in organic farming (199nmol g ${ }^{-1}$ soil h$^{-1}$ ) followed by conventional farming (130 nmol g ${ }^{-1}$ soil $\mathrm{h}^{-1}$ ) and forest soil $\left(19 \mathrm{nmol} \mathrm{g}^{-1}\right.$ soil h$\left.^{-1}\right)$ in the topsoil layer. The activity of cellobiohydrolase was higher in organic farming compared to forest soil, but was similar in organic and conventional farming soil. In contrast, xylanase activity was higher under conventional farming $(27 \mathrm{nmol}$ $\mathrm{g}^{-1}$ soil $\mathrm{h}^{-1}$ ) followed by organic farming $\left(17 \mathrm{nmol} \mathrm{g}^{-1}\right.$ soil $\left.\mathrm{h}^{-1}\right)$ and forest soil $(12 \mathrm{nmol}$ $\mathrm{g}^{-1}$ soil $\left.\mathrm{h}^{-1}\right)$. The activities of $\mathrm{N}$-cycle enzymes (chitinase, leucine amino-peptidase and tyrosine aminopeptidase) in the topsoil layer were higher under organic farming (138, 276 and $255 \mathrm{nmol} \mathrm{g}^{-1}$ soil $\mathrm{h}^{-1}$, respectively) compared with other land-use systems. The activities of tyrosine aminopeptidase and chitinase were also higher in subsoil under organic farming. Acid phosphatase (P-cycle) activity in topsoil was affected by land use. In contrast to $\mathrm{C}$ - (except xylanase) and $\mathrm{N}$-cycle enzymes, the activity of acid phosphatase in the topsoil layer was higher under 
conventional farming (936 nmol g $\mathrm{g}^{-1}$ soil $\mathrm{h}^{-1}$ ) followed by forest $\left(672 \mathrm{nmol} \mathrm{g}^{-1}\right.$ soil h $\left.\mathrm{h}^{-1}\right)$ and organic farming soil $\left(118 \mathrm{nmol} \mathrm{g}^{-1}\right.$ soil h$\left.^{-1}\right)$. Li et al., (2018) observed that compared with CK, NPSM and NPS treatments caused greater measures of G+ and G- biomarkers by $107-160 \%$ and $106-110 \%$, and greater measures of actinomycetes by $66-86 \%$. The NPSM and NPS treatments were also greater in abundances of fungal communities, the saprophytic fungi were greater by $123-135 \%$ and AMF was greater by $88-96 \%$. The $\mathrm{G}+/ \mathrm{G}-$ ratio was higher under NPSM treatment compared to other treatments, indicating that NPSM fertilization had changed soil microbial communities.

Naresh et al., (2018) revealed that in the turning jointing stage, compared with $\mathrm{CT}$, the ZT and FIRB treatments significantly increased nitrifying bacteria $[\mathrm{Gn}]$ by $77 \%$ and $229 \%$, respectively. At the booting stage, the Gn rates in ZT and FIRB soils were 2.16 and 3.37 times greater than that in CT soil, respectively. At the milking stage, the Gn rates in ZT and FIRB soils were 1.96 and 3.08 times greater than that in CT soil, respectively. Similarly, the denitrifying bacteria [D] rates of the different treatments. In the jointing stage, the D rates in ZT and FIRB soils were 2.77 and 2.26 times greater than that in CT soil. At the booting stage, compared with $\mathrm{CT}$, the $\mathrm{ZT}$ and FIRB treatments significantly increased D by $3.03 \%$ and $2.37 \%$, respectively. At the milking stage, the ZT and FIRB treatments increased $\mathrm{D}$ by $3.39 \%$ and $2.95 \%$, respectively. The $\mathrm{Gn}$ rates of the different treatments were $T_{6}>T_{3}>T_{4}>T_{7}$. The $D$ rates were $T_{3}>T_{6}>T_{2} \geq T_{4}$.Moreover, FIRB system with residue retention showed statistically significant differences in the phosphatase enzyme activity in the soil comparing with ZT with residue removal and CT. The activity of phosphatase tended to be higher in the FIRB treatment compared to the $\mathrm{ZT}$ and $\mathrm{CT}$ treatments.
Across the management practices evaluated in the review paper, tillage had the greatest effect on SOC and its various fractions and in the surface $(0-15 \quad \mathrm{~cm})$ soil of tillage implementation, with positive results observed with conservation tillage practices compared with conventional tillage. SOC stocks and those of the labile fractions decreased in topsoil and subsoil below $20 \mathrm{~cm}$ following land conversion. The LOC fractions to SOC ratios also decreased, indicating a reduction in $\mathrm{C}$ quality as a consequence of land use change. Reduced LOC fraction stocks in subsoil could partially be explained by the decrease in fine root biomass in subsoil, with consequences for SOC stock. However, not all labile fractions could be useful early indicators of SOC alterations due to land use change.

In fact, only fPOC, LFOC, and MBC in topsoil, and LFOC and DOC in subsoil were highly sensitive to land use change in subtropical climatic conditions of North West IGP. There was a significant reduction in SMBC content with depth in all treatments. SMBC in the PRB treatment increased by $19.8 \%, 26.2 \%, 10.3 \%, 27.7 \%, 10 \%$ and $9 \%$ at $0-5,5-10,10-20,20-40,40-60$ and 60-90 $\mathrm{cm}$ depths, respectively, when compared with the TT treatment. The mean SMBC of the PRB treatment was $14 \%$ higher than that in the TT treatment.

Conventional tillage in comparison with NT significantly reduced macro-aggregates with a significant redistribution of aggregates - into micro-aggregates. Aggregate protected labile $\mathrm{C}$ and $\mathrm{N}$ were significantly greater for macroaggregates, (>2000 and 250-2000 $\mu \mathrm{m})$ than micro-aggregates (53-250 and 20-53 $\mu \mathrm{m})$ and greater for $\mathrm{M}$ than $\mathrm{F}$ indicating physical protection of labile $\mathrm{C}$ within macroaggregates. No -tillage and $\mathrm{M}$ alone each significantly increased soil aggregation and aggregate-associated $\mathrm{C}$ and $\mathrm{N}$; however, NT and $\mathrm{M}$ together further improved soil aggregation and aggregate-protected $\mathrm{C}$ and $\mathrm{N}$. 
The distribution pattern of soil microbial biomass associated with aggregates was likely governed by the size of aggregates, whereas the tillage effect was not significant at the aggregate-size scale. Tillage regimes that contribute to greater soil aggregation also will improve soil microbial activity to aid in crop production. Heterogeneous distribution of OC and microbial biomass may lead to "hot-spots" of aggregation, and suggests that microorganisms associated with $1.0-2.0 \mathrm{~mm}$ aggregates are the most biologically active in the ecosystem.

Conventional tillage (CT) significantly reduces macro-aggregates to smaller ones, thus aggregate stability was reduced by $35 \%$ compared with conservation system (CS), further indicating that tillage practices led to soil structural damage. The concentrations of SOC and other nutrients are also significantly higher under CS than CT, implying that CS may be an ideal enhancer of soil productivity in this sub-tropical ecosystem through improving soil structure which leads to the protection of SOM and nutrients, and the maintenance of higher nutrient content. In conclusion, SOC, microbial biomasses and carbon fractions in the macro-aggregates are more sensitive to manure amendment than in the micro-aggregates. Conservation tillage benefited soil structure, increased microbial activities, and most likely aggregate distribution and stability especially soil fertility.

\section{References}

lemayehu, N., Masafu, M.M., Ebro, A. and Tegegne, A. 2016. Impact of tillage type and soil texture to soil organic carbon storage: The case of Ethiopian smallholder farms. African J Agri Res, 11(13):1126-1133

Aulakh, M.S., Garg, A. K., and Kumar, Shrvan. 2013. Impact of Integrated Nutrient, Crop Residue and Tillage Management on Soil Aggregates and Organic Matter Fractions in
Semiarid Subtropical Soil under SoybeanWheat Rotation. Am. J Plant Sci., 4:21482164

Baker JM., et al., 2007. Tillage and soil carbon sequestration-what do we really know? Agri Ecosyst Environ., 118(1-4):1-5.

Bandick A K and Dick R P. 1999. Field management effects on soil enzyme activities. Soil Biol Biochem 31: 1471-79.

Batjes, N.H., 2016. Harmonized soil property values for broad-scale modelling (WISE30sec) with estimates of global soil carbon stocks. Geoderma 269, 61-68.

Belay-Tedla A, Zhou X, Su B, Wan S and Luo Y. 2009. Labile, recalcitrant and microbial carbon and nitrogen pools of a tall grass prairie soil in the US Great Plains subjected to experimental warming and clipping. Soil Biol Biochem 41: 110-16.

Bhattacharyya R, Pandey SC, Bisht JK, Bhatt JC, Gupta HS, Tuti MD, et al., 2013.Tillage and Irrigation Effects on Soil Aggregation and Carbon Pools in the Indian Sub Himalayas. Agro J. 105(1):101-112

Blair GJ, et al., 1995. Soil carbon fractions based on their degree of oxidation and the development of a carbon management index for agricultural system. Aust J Agri Res., 46: 1459-1466.

Carter M R. 1996. Analysis of soil organic matter storage in agro-ecosystems In: Carter M R and Stewart B A (ed) Structure and Organic Matter Storage in Agricultural Soils. Pp. 311. CRC/Lewis Publishers, Boca Raton, FL.

Chu, J., Zhang, T., Chang, W., Zhang, D., Zulfiqar, S., Fu, A. and Hao, Y. 2016. Impacts of cropping systems on aggregates associated organic carbon and nitrogen in a semiarid highland Agro-ecosystem. PLOS ONE 11(10): 16-50.

Churchman, G.J., 2018. Game changer in soil science: functional role of clay minerals in soil. J. Plant Nutr. Soil Sci. 181, 99-103.

Das D, Dwivedi BS, Singh VK, Datta SP, Meena MC, Chakraborty D et al.,2017. Long-term effects of fertilizers and organic sources on soil organic carbon fractions under a ricewheat system in the Indo-Gangetic Plains of northwest India. Soil Res, http://dx.doi.org/10.1071/SR 16097

Debasish S, Kukal S S and Sharma S. 2011. Land 
use impacts on SOC fractions and aggregate stability in typic ustochrepts of Northwest India. Plant Soil 339: 457-70.

Dhaliwal J, Kukal SS, Sharma S.2018.Soil organic carbon stock in relation to aggregate size and stability under tree based cropping systems in Typic Ustochrepts. Agroforestry Syst. 92(2):275-284.

Divya, P., Madhoolika, A., and Jitendra, S.B. 2014. Effects of conventional tillage and no tillage permutations on extracellular soil enzyme activities and microbial biomass under rice cultivation. Soil Tillage Res. 136: 51-60.

Dou F, Wright AL, Hons FM. 2008. Sensitivity of labile soil organic carbon to tillage in wheatbased cropping systems. Soil Sci Soc Am J. 72:1445-1453.

Eswaran, H., Reich, P.F., Beinroth, F.H., Padmanabhan, E., Moncharoen, P., 2000. Global carbon stocks. In: Lal, R., Kimble, J.M., Eswaran, H., Stewart, B.A. (Eds.), Global Climate Change and Pedogenic Carbonates. Lewis Publishers, Boca Raton, FL, USA, pp. 15-26.

Fernández-Ugalde,O., Virto,I., Bescansa, P., Imaz, M.J., Enrique,A., and Karlen, D.L. 2009. Notillage improvement of soil physical quality in calcareous, degradation-prone, semiarid soils. Soil Tillage Res, 106(1):29-35

Gabarron-Galeote, M.A., Trigalet, S., van Wesemael, B., 2015. Effect of land abandonment on soil organic carbon fractions along a Mediterranean precipitation gradient. Geoderma 249-250, 69-78.

Gu C, Li Y, Mohamed I, Zhang R, Wang X, Nie X, Jiang M, and Margot B. 2016. Dynamic Changes of Soil Surface Organic Carbon under Different Mulching Practices in Citrus Orchards on Sloping Land. PLoS ONE. 11(12): 0168384.

doi:10.1371/ journal.pone. 0168384

Hati KM., et al., 2014.Conservation Tillage Effects on Soil Physical Properties, Organic Carbon Concentration and Productivity of Soybean- Wheat Cropping System. J Agri Phys 14: 121-129.

Hassink, J., 2016. The capacity of soils to preserve organic $\mathrm{C}$ and $\mathrm{N}$ by their association with clay and silt particles. Plant and Soil 191, 7787.
Haynes RJ. 2005. Labile organic matter fractions as central components of the quality of agricultural soils: an overview. Adv Agron., 85: 221-268.

He Y, Xu Z H, Chen C R, Burton J, Ma Q, Ge Y and $\mathrm{Xu}$ J M. 2008. Using light fraction and macro-aggregate associated organic matters as early indicators for management-induced changes in soil chemical and biological properties in adjacent native and plantation forests of subtropical Australia. Geoderma 147: 116-25.

Huang Z Q, Xu Z H, Chen C R and Boyd S. 2008. Changes in soil carbon during the establishment of a hardwood plantation in subtropical Australia. Forest Ecol Manage 254: 46-55.

Jastrow J D, Miller R M and Lussenhop J. 1998. Contributions of interacting biological mechanisms to soil aggregate stabilization in restored prairie. Soil Biol Biochem 30: 90516.

Jiang, X., Wright, A.L., Wang, J., and Li, Z. 2011. Long-term tillage effects on the distribution patterns of microbial biomass and activities within soil aggregates. Catena 87:276-280.

Jobba'gy, E.G., Jackson, R.B., 2000. The vertical distribution of soil organic carbon and its relation to climate and vegetation. Ecol. Appl. 10, 423-436.

Juan Li, Yanchen Wen, Xuhua Li, Yanting Li, Xiangdong Yang, Zhian Lin et al., 2018. Soil labile organic carbon fractions and soil organic carbon stocks as affected by longterm organic and mineral fertilization regimes in the North China Plain. Soil Tillage Res.175:281-290

Kashif, Ali Kubar, Li Huang, Jianwei Lu, Bin Xin, Zhiya Yin. 2019. Long-term tillage and straw returning effects on organic $\mathrm{C}$ fractions and chemical composition of SOC in rice-rape cropping system. Archives Agro Soil Sci.65. https://doi.org/10.1080/03650340.2018.14907 26

Krishna, C. A., Majumder, S.P., Padhan, D., Badole, S., Datta,A., Mandal, B., and Gade, K.R. 2018. Carbon dynamics, potential and cost of carbon sequestration in double rice cropping system in semi-arid southern India. J. Soil Sci Plant Nutri, 18 (2): 418-434

Kumar R, Rawat K S, Singh J, Singh A and Rai A. 
2013. Soil aggregation dynamics and carbon sequestration. J Appl Nat Sci 5: 250-67.

Kumar, V., Naresh, R.K., Satendra Kumar, Sumit Kumar, Sunil Kumar, Vivak, Singh, S.P., and Mahajan, N.C. 2018. Tillage, crop residue, and nitrogen levels on dynamics of soil labile organic carbon fractions, productivity and grain quality of wheat crop in Typic Ustochrept soil. J. Pharmacog Phytochem. 7(1): 598-609.

Kumari M., et al., 2011. Soil aggregation and associated organic carbon fractions as affected by tillage in a rice-wheat rotation in North India". Soil Sci Soc Am J. 75: 562567.

Kushwaha CP, Tripathi SK, Singh KP.2000. Variations in soil microbial biomass and $\mathrm{N}$ availability due to residue and tillage management in a dry-land rice agroecosystem. Soil Tillage Res. 56:153-166.

Lal, R., Follett, R.F., 2009. Soil Carbon Sequestration and the Greenhouse Effect, second ed. Soil Science Society of America, Inc., Madison, Wisconsin, USA.

Li, J., Wu, X., Gebremikael, M.T., Wu, H., Cai, D., Wang, B., et al., 2018. Response of soil organic carbon fractions, microbial community composition and carbon mineralization to high- input fertilizer practices under an intensive agricultural system. PLoS ONE 13(4): e0195144.

Liang B, Yang X, He X, Zhou J.2011. Effects of 17-year fertilization on soil microbial biomass $\mathrm{C}$ and $\mathrm{N}$ and soluble organic $\mathrm{C}$ and $\mathrm{N}$ in loessial soil during maize growth. Biol. Fertility Soils. 47(2):121-128.

Liu E, Yan C, Mei X, Zhang Y, Fan T.2013. LongTerm Effect of Manure and Fertilizer on Soil Organic Carbon Pools in Dryland Farming in Northwest China. PLoS ONE. 8(2):e56536. https://doi.org/10.1371/journal.pone.005 6536

Ma Z, Chen J, Lyu X, Liu Li-li, Siddique KHM. 2016. Distribution of soil carbon and grain yield of spring wheat under a permanent raised bed planting system in an arid area of northwest China. Soil Tillage Res.163:274281.

Maharning A R, Mills A A S and Adl S M.2009. Soil community changed during secondary succession to naturalized grasslands. Appl
Soil Ecol 41: 137-41.

Maharjana, M., Sanaullaha, M., Razavid, B.S., and Kuzyakov, Y. 2017. Effect of land use and management practices on microbial biomass and enzyme activities in subtropical top-and sub-soils. Appl Soil Ecol. 113: 22-28.

Mahajan, N.C., Kancheti Mrunalini, K.S. Krishna Prasad, K.S.,Naresh, R.K., and Lingutla Sirisha. 2019. Soil Quality Indicators, Building Soil Organic Matter and Microbial Derived Inputs to Soil Organic Matter under Conservation Agriculture Ecosystem: A Review. Int. J. Curr. Microbiol. App. Sci. 8(2):1859-1879

Malviya, S.R. 2014. Effect of conservation agricultural practices on selected soil physical properties and carbon pools in black soils of central India. M.Sc. Thesis, Jawaharlal Nehru Krishi Vishwa Vidyalaya, Jabalpur, M. P.

Mamta, Kumari., Chakraborty, D., Gathala, Mahesh, K., Pathak, H.,Dwivedi, B.S., Tomar, R.K., Garg, R.N., Singh, R., and Ladha, J.K. 2014. Soil Aggregation and Associated Organic Carbon Fractions as Affected by Tillage in a Rice-Wheat Rotation in North India. Soil Sci. Soc. Am. J. 75:560567.

Mandal N, Dwivedi BS, Meena MC, Singh D, Datta SP, Tomar RK et al., 2013. Effect of induced defoliation in pigeonpea, farmyard manure and sulphitation press-mud on soil organic carbon fractions, mineral nitrogen and crop yields in a pigeon-pea-wheat cropping system. Field Crops Res.154:178187

Mangalassery, S., Sjogersten, S.,Sparkes, D.L., Sturrock, C.J., Craigon, J., and Mooney, S.J. 2014. To what extent can zero tillage lead to a reduction in greenhouse gas emissions from temperate soils? Sci Rep. 4: 4586 | DOI: 10.1038/srep04586

McGonigle, T.P., andTurner, W.G. 2017. Grasslands and Croplands Have Different Microbial Biomass Carbon Levels per Unit of Soil Organic Carbon. Agriculture, 7, 57; doi:10.3390/agriculture7070057

Moussadek, R.,Mrabet,R., Dahan,R., Zouahri, A., El Mourid, M., and Van Ranst, E. 2014. Tillage System Affects Soil Organic Carbon Storage and Quality in Central Morocco. Appl Environ Soil Sci. ID 654796, 8. 
Naresh RK., et al., 2015. Tillage crop establishment strategies and soil fertility management: resource use efficiencies and soil carbon sequestration in a rice-wheat cropping system. Ecol Environ \& Conserv., 21: S121-S128.

Naresh RK, Gupta Raj K, Singh SP, Dhaliwal SS, Ashish Dwivedi, Onkar Singh et al., 2016. Tillage, irrigation levels and rice straw mulches effects on wheat productivity, soil aggregates and soil organic carbon dynamics after rice in sandy loam soils of subtropical climatic conditions. J Pure Appl Microbiol, 10(2):1061-108

Naresh RK, Arvind Kumar, Bhaskar S, Dhaliwal SS, Vivek, Satendra Kumar et al., 2017. Organic matter fractions and soil carbon sequestration after 15 - years of integrated nutrient management and tillage systems in an annual double cropping system in northern India. J Pharmacog Phytochem.6(6):670-683.

Naresh, R.K.,Gupta,R.K., Vivek, Rathore, R.S., Singh, S.P.,Kumar, A., Sunil Kumar,Sachan, D.K., Tomar, S.S.,Mahajan, N.C., Lali Jat and Mayank Chaudhary. 2018. Carbon, Nitrogen Dynamics and Soil Organic Carbon Retention Potential after 18 Years by Different Land Uses and Nitrogen Management in RWCS under Typic Ustochrept Soil. Int. J. Curr. Microbiol. App. Sci. 7(12): 3376-3399.

Ou, H.P., Liu, X.H., Chen, Q.S., Huang, Y.F., He, M.J., Tan, H.W., Xu, F.L., Li, Y.R., and Gu, M.H. 2016. Water-Stable Aggregates and Associated Carbon in a Subtropical Rice Soil under Variable Tillage. Rev Bras Cienc Solo. 40: $145-150$.

Paustian, K., Andr en, O., Janzen, H.H., Lal, R., Smith, P., Tian, G., Tiessen, H., Van Noordwijk, M., Woomer, P.L., 1997. Agricultural soils as a sink to mitigate $\mathrm{CO}_{2}$ emissions. Soil Use Manage. 13, 230-244.

Pulleman M M and Marinissen J C Y. 2004. Physical protection of mineralizable carbon in aggregates from long-term pasture and arable soil. Geoderma 120: 273-82.

Rajan G., et al., 2012. Soil organic carbon sequestration as affected by tillage, crop residue, and nitrogen application in ricewheat rotation system". Paddy Water Environ., 10: 95-102.
Rudrappa L., et al.,2006. Long-term manuring and fertilization effects on soil organic carbon pools in a Typic Haplustept of semi-arid subtropical India. Soil Tillage Res 88:180192.

Sheng, H., Zhou, P., Zhang, Y., Kuzyakov, Y., Zhou, Q., Ge, T., and Wang, C. 2015. Loss of labile organic carbon from subsoil due to land-use changes in subtropical China.Soil Biol Biochem. 88: 148-157

Shepherd T G, Saggar S, Newman R H, Ross C W and Dando J L. 2001.Tillage-induced changes to soil structure and organic carbon fractions in New Zealand soils. Aust J Soil Res 39: 465-89.

Simansky, V., Horak, J., Clothier, B., Buchkina, N., and Igaz, D. 2017.Soil organic-matter in water-stable aggregates under different soilmanagement practices. Agric. 63 (4):151162.

Sinsabaugh R L, Antibus R K and Linkins A E. 1991. An enzymic approach to the analysis of microbial activity during plant litter decomposition. Agric Ecosyst Environ 34: 43-54.

Six J., et al., 2000. Soil structure and organic matter: I. Distribution of aggregate-size fractions and aggregate-associated carbon. Soil Sci Soc Am J. 64: 681-689.

Song, K., Yang, J., Xue, Y., Weiguang, L., Zheng, X. and Pan, J. 2016. Influence of tillage practices and straw incorporation on soil aggregates, organic carbon, and crop yields in a rice-wheat rotation system. Sci Rep 6:36602.

Spedding, T.A., Hamel, C., Mehuys, G.R. and Madramootoo, C.A. 2004.Soil microbial dynamics in maize-growing soil under different tillage and residue management systems. Soil Biol. Biochem., 36:499-512.

Spohn M and Giani L. 2011. Impacts of land use change on soil aggregation and aggregate stabilizing compounds as dependent on time. Soil Biol Biochem 43: 1081-88.

Stevenson F J.1994. Humus Chemistry: Genesis, Composition, Reaction. Pp. 496. 2nd Ed Wiley, New York.

Stockmann, U., Adams, M.A., Crawford, J.W., Field, D.J., Henakaarchchi, N., Jenkins, M., Minasny, B., McBratney, A.B., de Remy de Courcelles, V., Singh, K., Wheeler, I., 
Abbott, L., Angers, D.A., Baldock, J., Bird, M., Brookes, P.C., Chenu, C., Jastrow, J.D., Lal, R., Lehmann, J., O’Donnell, A.G., Parton, W.J., Whitehead, D., Zimmermann, M., 2013. The knowns, known unknowns and unknowns of sequestration of soil organic carbon. Agric. Ecosyst. Environ. 164, 80-99.

Tiessen, H., Stewart, J.W.B., 1983. Particle-size fractions and their use in studies of soil organic matter: II. Cultivation effects on organic matter composition in size fractions. Soil Sci. Soc. Am. J. 47, 509-514.

Von-Lutzow M, Leifeld J, Kainz M, KogelKnabner I and Munch J C. 2000. Indications for soil organic matter quality in soils under different management. Geoderma 105: 24358.

Wander M. 2004. Soil organic matter fractions and their relevance to soil function. In: Magdoff $F$ and Weil R R (ed) Soil organic matter in sustainable agriculture. Pp 67-102. CRC Press, Boca Raton, FL.

Wang W, Lai DYF, Wang C, Pan T, Zeng C. 2015. Effects of rice straw incorporation on active soil organic carbon pools in a subtropical paddy field. Soil Tillage Res. 152:8-16.

Wang, G. C., Luo, Z., Han, P., Chen, H., and Xu, J. 2016. Critical carbon input to maintain current soil organic carbon stocks in global wheat systems, Sci. Rep.-6: 19327, https:// doi. org/10.1038/srep19327

Wang, H., Wang, S., Zhang, Y., Wang, X., Wang, R., and Li, J. 2018. Tillage system change affects soil organic carbon storage and benefits land restoration on loess soil in North China. https://doi.org/10.1002/ldr.3015

Xu, S. Q., Zhang, M. Y., Zhang, H. L., Chen, F., Yang, G. L. and Xiao, X. P. 2013. Soil organic carbon stocks as affected by tillage systems in a double-cropped rice field. Pedosphere. 23(5): 696-704.

Xue J., et al., 2015. Effects of tillage systems on soil organic carbon and total nitrogen in a double paddy cropping system in Southern China.

Soil Tillage Res., 153: 161-168.

Yadvinder-Singh., et al., 2005.Crop residue management for nutrient cycling and improving soil productivity in rice-based cropping systems in the tropics. Adv Agron 85: 269-407.

Yang CM., et al., 2005. Organic carbon and its fractions in paddy soil as affected by different nutrient and water regimes. Geoderma 124: 133-142.

Zeebe, R.E., Ridgwell, A., Zachos, J.C., 2016. Anthropogenic carbon release rate unprecedented during the past 66 million years. Nat. Geosci. 9, 325-329.

Zhang-liuDU., et al., 2013. Soil Aggregate Stability and Aggregate-Associated Carbon under Different Tillage Systems in the North China Plain. J. Integ Agri 12 (11): 21142123.

Zheng H, Liu W, Zheng J, Luo Y, Li R, Wang H, et al., 2018. Effect of long-term tillage on soil aggregates and aggregate-associated carbon in black soil of Northeast China. PLoS ONE 13(6): e0199523.

Zhou H., et al., 2013. Effects of organic and inorganic fertilization on soil aggregation in an ultisol as characterized by synchrotron based X-ray micro-computed tomography. Geoderma 196: 23-30.

Zhu L, Hu N, Zhang Z, Xu J, Tao B, Meng Y. 2015. Short-term responses of soil organic carbon and carbon pool management index to different annual straw return rates in a ricewheat cropping system. Catena.135:283-289.

\section{How to cite this article:}

Arvind Kumar, R. K. Naresh, Shivangi Singh, N. C. Mahajan and Omkar Singh. 2019. Soil Aggregation and Organic Carbon Fractions and Indices in Conventional and Conservation Agriculture under Vertisol soils of Sub-tropical Ecosystems: A Review. Int.J.Curr.Microbiol.App.Sci. 8(10): 2236-2253. doi: https://doi.org/10.20546/ijcmas.2019.810.260 